\title{
Effect of napier grass supplemented with Gliricidia sepium, Sapindus rarak or Hibiscus rosa-sinensis on in vitro rumen fermentation profiles and methanogenesis
}

\author{
P. Yuliana ${ }^{1}$, E.B. Laconi ${ }^{2}$, A. Jayanegara ${ }^{2}$, S. S. Achmadi ${ }^{3}$ and A. A. Samsudin ${ }^{4, *}$ \\ ${ }^{1}$ Graduate School of Nutrition and Feed Science, Faculty of Animal Science, \\ IPB University, Jl. Agatis, Dramaga Campus, Bogor 16680 - Indonesia \\ ${ }^{2}$ Department of Nutrition and Feed Technology, Faculty of Animal Science, \\ IPB University, Jl. Agatis, Dramaga Campus, Bogor 16680 - Indonesia \\ ${ }^{3}$ Department of Chemistry, Faculty Mathematics and Natural Sciences, \\ IPB University, Jl. Meranti, Dramaga Campus, Bogor 16680 - Indonesia \\ ${ }^{4}$ Department of Animal Science, Faculty of Agriculture, Universiti Putra Malaysia, \\ Serdang, Selangor 43000 - Malaysia \\ *CorrespondingE-mail: anjas@upm.edu.my
}

Received October 22, 2018; Accepted February 02, 2019

\begin{abstract}
ABSTRAK
Penelitian ini menguji efek suplementasi daun gamal (DG, Gliricidia sepium), buah lerak (BL, Sapindus rarak), atau daun kembang sepatu (DKS, Hibiscus rosa-sinensis) pada rumput gajah (RG, Pennisetum purpureum) terhadap fermentasi rumen dan metanogenesis secara in vitro. Rancangan percobaan yang dilakukan adalah rancangan acak kelompok dengan tujuh perlakuan dan empat ulangan. Perlakuan yang diujikan meliputi: RG, DG, BL, DKS, RG 70\% + DG 30\%, RG 70\% + BL 30\%, dan RG $70 \%+$ DKS 30\%. Peubah yang diamati adalah kandungan nutrien, produksi gas, kecernaan, profil volatile fatty acid (VFA), amonia dan populasi mikroba rumen. Data kemudian dianalisis menggunakan analisis ragam (ANOVA) dan dilanjutkan dengan uji Duncan untuk membandingkan antar perlakuan. Hasil menunjukkan bahwa suplementasi pakan mengandung saponin seperti LF atau HL pada NG tidak mengubah produksi gas pada waktu inkubasi 24 dan 48 jam. Pakan HL baik tunggal maupun kombinasi dengan NG menghasilkan kecernaan bahan organik tertinggi dibandingkan dengan perlakuan lainnya $(\mathrm{P}<0.05)$. Suplementasi LF menurunkan emisi gas metana dibandingkan dengan $\mathrm{NG}$ tunggal $(\mathrm{P}<0.05)$, serta mengubah profil VFA menjadi lebih tinggi propionat dan lebih rendah asetat $(\mathrm{P}<0.05)$. Suplementasi LF cenderung menurunkan populasi protozoa rumen namun tidak mengubah populasi metanogen. Dapat disimpulkan bahwa penggunaan pakan tinggi saponin bermanfaat dalam menurunkan emisi gas metana di dalam rumen.
\end{abstract}

Kata kunci:In vitro, fermentasi rumen, produksi gas, saponin, kecernaa

\section{ABSTRACT}

This study examined the supplementation effects of gliricidia leaves (GL, Gliricidia sepium), lerak fruit (LF, Sapindus rarak), or hibiscus leaves (HL, Hibiscus rosa-sinensis) on in vitro rumen fermentation and methanogenesis and made a comparison with the Napier grass (NG, Pennisetum purpureum) grass. In vitro rumen fermentation was designed according to a randomized complete block design with four replications and seven treatments: NG, GL, LF, HL, NG 70\% + GL 30\%, NG 70\% + 
LF $30 \%$ and NG 70\% + HL 30\%. The generated data were subjected to analysis of variance (ANOVA) with Duncan's multiple range test and compared among treatment means. Addition of a plant containing saponin such as LF or HL to NG did not alter gas production after 24 and $48 \mathrm{~h}$ of incubation period in comparison to NG alone. The HL alone or blended with NG produced the highest IVOMD during the fermentation process as compared to other treatments $(\mathrm{P}<0.05)$. Adding LF supplement either singly or in combination significantly $(\mathrm{P}<0.05)$ reduced methane production in terms of \%TVFA as compared to NG. Supplementation of LF plants has shifted VFA proportion towards more propionate and less acetate. The microbial population of LF, whether single or in combination had a tendency to reduce the rumen protozoa population but had no effect on methanogen population. It can be concluded that utilization of saponin-rich materials is particularly beneficial for reducing ruminal methane emission.

Keywords:In vitro, rumen fermentation, gas production, saponins, digestibility.

\section{INTRODUCTION}

Napier grass (Pennisetum purpureum) is a widely used forage species for ruminant feeding in the tropics. It is known to have high nutritive value among grass species and therefore is viewed as a suitable perennial fodder ideal for intensively managed livestock production systems. The commonly practiced feeding management is cutand-carry. However, a diet of napier grass alone is nutritionally insufficient, particularly protein requirements of ruminants. As such, supplementation of napier grass with other high protein feedstuffs such as gliricidia leaves (Gliricidia sepium) is necessary to close the gap between nutrients available in feeds and nutrient requirements of the animals. Gliricidia is a leguminous tree widely used in the semi-arid and sub-humid tropics containing high protein content, low fiber, and highly digestible. This medium-sized plant grows abundantly and is able to preserve its high quality even at the height of the dry season. It is extensively utilized in the cattle-rearing industry as a natural defence and source of nutrition during dry seasons (Wood et al., 1998). The plant has been known to be potentially good for sustaining increased livestock production (National Academy of Sciences, 1977) and potential to enhance the productivity and sustainability of agricultural systems (Dawson et al., 1996).

On the other hand, feeding of high-fiber feedstuffs such as grasses and agricultural residues generally results in a high enteric methane emission. Methane is among the main sources of greenhouse gases in the atmosphere (Tian et al., 2016) and livestock is a key source of greenhouse gas emissions, particularly methane. Enteric fermentation of feed by ruminants is one of the most substantial sources of anthropogenic methane emissions, i.e. as much as $25 \%$ of the total methane emissions (Hristov et al., 2017). Besides its significant contribution to global warming, methane emission from ruminants also results in the loss of approximately 5-9\% of dietary gross energy (Jeyanathan et al., 2014) that would otherwise be used to support productivity.

An approach to mitigate enteric methane emission from ruminants is by using natural compounds such as tannin, saponin, and essential oil. Some efforts have been made and been proved to be effective in lowering the methane emission (Cottle et al., 2011). Methane from ruminants may be notified by type of diet as a result of the disparity in their chemical make up or the existence of some plant secondary metabolites (saponins, tannins, etc.) or other unknown constituents in feeds reported earlier by Prusty et al. (2014). Outcomes of plant secondary metabolites or extracts on methane emissions have been earlier documented by Kumar et al. (2014). Natural compounds are favoured (Kondo et al., 2014), particularly after the use of antibiotics was banned as feed additives in several countries. Plants originating from the tropics are, in general, high in these natural compounds including saponin. Lerak fruits (Sapindus rarak) and hibiscus or rose mallow leaves (Hibiscus rosa-sinensis) have been reported to contain considerable amounts of saponin (Wina et al., 2006), which comprise aglycon (steroid or triterpenoid) and glycon structures (Cheok et al., 2014). This structure provides saponin with a membranolytic activity (Wojciechowski et al., 2016) and clarifies their role in reducing methane emission in vitro (Rira et al., 2015), therefore possessing the potential to be used as methane mitigating agents.

The aim of this study was to evaluate the partial replacement of gliricidia leaves, lerak 
fruits or hibiscus leaves in napier grass, especially with regard to their influences on methanogenesis and rumen fermentation in vitro.

\section{MATERIALS AND METHODS}

\section{Determination of Chemical Composition}

Feed samples were subjected to analysis for contents of dry matter (DM), crude protein (CP), ether extract (EE), crude fiber (CF), ash in line with AOAC procedure (AOAC, 1990). Neutral detergent fiber (NDF), acid detergent fiber (ADF) and acid detergent lignin (ADL) were evaluated by following Van Soest et al. (1991). Analysis of total saponin was done in accordance with the method of Hiai and Nakajima (1976) and calibrated against diosgenin standard (SigmaAldrich D1634, Sigma Aldrich Chemie GmbH, Steinheim, Germany).

\section{In vitro Rumen Fermentation Procedure}

Samples of napier grass (NG), gliricidia leaves (GL), lerak fruits (LF) and hibiscus leaves (HL) were subjected to in vitro incubation by using buffered rumen fluid (Menke and Steingass, 1988). The experimental treatments were: NG, GL, LF, HL, NG 70\% + GL 30\%, NG 70\% + LF $30 \%$, and NG $70 \%+$ HL $30 \%$. Rumen fluid was sourced from two fistulated Brahman-cross cattle prior to the morning feed, filtered and mixed with buffer solution in ratio (rumen fluid: buffer) 1:4 $\mathrm{v} / \mathrm{v}$. The incubation was performed in four replicates by employing a randomized complete block design. Total gas generated was noted at 0 , $3,6,9,12,24,30,36$, and $48 \mathrm{~h}$ following incubation employing a gas syringe. The kinetic parameters of in vitro cumulative gas produced were estimated as per Ørskov and McDonald (1979).

The $\mathrm{pH}$ of rumen fluid samples was also noted with a $\mathrm{pH}$ meter while ammonia $\left(\mathrm{NH}_{3}\right)$ concentration was determined according to Parsons et al. (1984). Volatile fatty acids (VFA) were determined by employing a gas chromatograph (Hewlett Packard 6890 GC system) according to the procedure of Cottyn and Boucque (1968). Amount of methane produced was computed by employing the equation of Moss et al. (2000). The isolation of DNA from the rumen fluid sample was done with the use of CTAB DNA extraction (Neumann et al., 1992). The rumen microbial populations analyzed were total bacteria, methanogens, total protozoa, Fibrobacter succinogenes, Ruminococcus albus and Ruminococcus flavefaciens using BioRad CFX96 real-time PCR system. The real-time cycling condition was prepared as described by Muideen et al. (2017).

\section{Statistical Analysis}

The experiment on in vitro rumen fermentation used a randomized complete block design with four replicates, and with two incubation syringes representing each replicate. Different lots of rumen fluid (runs) made up the block. The obtained data were subjected to analysis of variance (ANOVA) and Duncan's multiple range test (Steel and Torrie, 1980).

\section{RESULTS AND DISCUSSION}

Crude protein contents of experimental diets varied from $3.55 \%$ in $\mathrm{LF}$ to $22.2 \% \mathrm{DM}$ in GL (Table 1). Such high CP observed in GL confirms its use as a protein supplement. Crude fiber contents differed from $1.15 \%$ to $35.3 \% \mathrm{DM}$, and similar with those of NDF, ADF and ADL contents. Both LF and HL contained a considerable amount of saponin.

Total gas production of GL, LF or HL, either individually or combined with NG is presented in Table 2. Addition of a plant containing saponin such as LF or HL to NG did not alter gas production after 24 and $48 \mathrm{~h}$ of incubation period in comparison to NG alone. During the in vitro fermentation process, the gas is produced as a result of substrates metabolism by the rumen microbes. Total gas production in vitro increased dramatically within the first $10 \mathrm{~h}$ of incubation and started to slow down because of the reduction of fermentable substrates. The decreasing quantity of fermentable substrates has been reported previously (Jayanegara et al., 2006). Different with the current finding, Herdian et al. (2011) reported that the gas production decreased significantly by supplementing the NG with Morinda citrifolia, a saponin-containing plant. By doing so, the saponin level increases from $5 \%$ to $10 \%$ of DM feed and consequently reduces the protozoa population and lowers the gas production (Teferedegne et al., 1999).

Gas production is essentially caused by microbial fermentation of carbohydrates to various volatile fatty acids in the rumen such as acetate, propionate and butyrate (Steingass and Menke, 1986), and considerable changes in carbohydrate fractions were evidenced by the total gas generated. In vitro OMD also varied among 
Table 1. Chemical Composition of Experimental Diets (\% Dry Matter)

\begin{tabular}{ccccccccccc}
\hline Diet & DM & OM & CP & EE & CF & NDF & ADF & ADL & Ash & Saponin \\
\hline NG & 95.2 & 84.5 & 9.06 & 1.41 & 35.3 & 78.1 & 36.4 & 21.9 & 4.80 & nd \\
GL & 88.3 & 91.3 & 22.2 & 4.17 & 12.4 & 55.8 & 27.2 & 18.8 & 8.69 & nd \\
LF & 95.5 & 89.7 & 3.55 & 0.57 & 1.15 & 17.5 & 16.7 & 5.33 & 3.25 & 36.4 \\
HL & 97.6 & 88.1 & 18.5 & 4.24 & 1.55 & 31.9 & 31.0 & 23.5 & 11.9 & 16.6 \\
NG 70\%+ & 94.0 & 86.5 & 13.0 & 2.23 & 28.4 & 71.4 & 33.6 & 21.0 & 5.97 & nd \\
GL 30\% & & & & & & & & & & \\
NG 70\%+ & 95.3 & 86.1 & 7.41 & 1.16 & 25.0 & 59.9 & 30.7 & 16.9 & 4.34 & 10.9 \\
LF 30\% & & & & & & & & & & \\
NG 70\%+ & 95.9 & 85.6 & 11.9 & 2.26 & 25.2 & 64.3 & 34.8 & 22.4 & 6.93 & 4.98 \\
HL 30\% & & & & & & & & & & \\
\hline NG: napier gras
\end{tabular}

NG: napier grass, GL: gliricidia leaves, LF: lerak fruits, HL: hibiscus leaves, DM: dry matter, OM: organic matter, $\mathrm{CP}$ : crude protein, EE: ether extract, $\mathrm{CF}$ : crude fiber, NDF: neutral detergent fiber, ADF: acid detergent fiber, ADL: acid detergent lignin, nd: not detected.

Table 2. Effect of Experimental Diets on In vitro Gas Production

\begin{tabular}{|c|c|c|c|c|c|}
\hline Diet & $\begin{array}{l}\text { Gas } 24 \mathrm{~h} \\
\quad(\mathrm{~mL})\end{array}$ & $\begin{array}{l}\text { Gas } 48 \mathrm{~h} \\
\quad(\mathrm{~mL})\end{array}$ & $\begin{array}{c}b \\
(\mathrm{~mL})\end{array}$ & $\begin{array}{c}c \\
(1 / \mathrm{h})\end{array}$ & $\begin{array}{c}\text { IVOMD } \\
(\%)\end{array}$ \\
\hline NG & $22.4 \pm 8.27^{\mathrm{abc}}$ & $31.5 \pm 6.54^{\mathrm{b}}$ & $36.1 \pm 8.25^{\mathrm{b}}$ & $0.01 \pm 0.01$ & $42.0 \pm 7.35^{\mathrm{bc}}$ \\
\hline GL & $16.5 \pm 6.67^{\mathrm{a}}$ & $20.9 \pm 8.07^{\mathrm{a}}$ & $24.7+9.91^{\mathrm{a}}$ & $0.05 \pm 0.01$ & $45.2 \pm 5.92^{\mathrm{cd}}$ \\
\hline $\mathrm{LF}$ & $17.6 \pm 11.28^{\mathrm{ab}}$ & $22.7 \pm 13.4^{\mathrm{a}}$ & $37.6 \pm 15.0^{\mathrm{b}}$ & $0.04 \pm 0.02$ & $34.2 \pm 10.0^{\mathrm{a}}$ \\
\hline $\mathrm{HL}$ & $30.7 \pm 8.32^{\mathrm{d}}$ & $36.9 \pm 7.60^{\mathrm{b}}$ & $38.5 \pm 4.71^{\mathrm{b}}$ & $0.07 \pm 0.03$ & $58.3 \pm 7.40^{\mathrm{e}}$ \\
\hline NG $70 \%+$ GL $30 \%$ & $23.9 \pm 6.25^{\mathrm{bc}}$ & $31.8 \pm 8.92^{b}$ & $38.8 \pm 8.30^{\mathrm{b}}$ & $0.04 \pm 0.03$ & $45.8 \pm 5.59^{\mathrm{cd}}$ \\
\hline NG $70 \%+$ LF $30 \%$ & $19.4 \pm 9.73^{\mathrm{ab}}$ & $30.0 \pm 5.35^{\mathrm{b}}$ & $36.3 \pm 3.77^{b}$ & $0.04 \pm 0.01$ & $38.2 \pm 8.66^{\mathrm{ab}}$ \\
\hline $\mathrm{NG} 70 \%+\mathrm{HL} 30 \%$ & $28.6 \pm 7.22^{\mathrm{cd}}$ & $33.3 \pm 4.73^{b}$ & $36.5 \pm 5.35^{\mathrm{b}}$ & $0.06 \pm 0.02$ & $50.8 \pm 6.42^{\mathrm{d}}$ \\
\hline SEM & 0.877 & 1.251 & 1.25 & 0.07 & 8.166 \\
\hline P-value & $<0.001$ & 0.002 & 0.003 & 0.237 & $<0.001$ \\
\hline
\end{tabular}

Different superscripts within the same column are statistically different at $\mathrm{P}<0.05$.

NG: napier grass, GL: gliricidia leaves, LF: lerak fruits, HL: hibiscus leaves, $b$ : potential gas production, $c$ : gas production rate constant, IVOMD: in vitro organic matter digestibility, SEM: standard error of mean

the experimental diets in this study $(\mathrm{P}<0.05)$. The $\mathrm{HL}$ alone or blended with NG produced the highest IVOMD during the fermentation process as compared to other treatments $(\mathrm{P}<0.05)$. It is generally accepted that any feedstuffs that would give higher gas production and IVOMD have a tendency to produce higher $\mathrm{CH}_{4}$ per gram DM incubated (Jayanegara et al., 2011). In general, the digestibility of Napier grass is affected by several factors, for instance, the cultivar selection and the management practices (Zailan et al., 2015). The asymptotic gas production (b) ranged from 24.7 to $38.8 \mathrm{~mL}$, and the rate of production (c) from 0.01 to $0.07 \mathrm{~h}-1$. The highest value of asymptotic gas 
production was observed in HL $(38.5 \mathrm{~mL})$ among the single incubated feedstuffs. The cell wall contents (NDF and ADF) were inversely related with gas production at all incubation times and $b$ parameter except the rate of gas production (c). The negative correlation between gas production and the cell wall contents may be caused by the decrease of microbial activity. This result is in line with findings of Abdulrazak et al. (2000). In this study, we agree with the report by Khazaal et al. (1993), Blummel and Orskov (1993), who noted a connection between DM disappearance and gas production, but they failed to identify a noteworthy association between the gas production rates (c).

The rumen $\mathrm{pH}$ values indicated a normal rumen condition, ranging from 6.8 to 7.1 . Supplementation of GL, LF or HL had no noteworthy impact on rumen $\mathrm{pH}$ (Table 3 ). These results are in agreement with those reported by Hess et al. (2003) who also failed to find any noteworthy alterations in the $\mathrm{pH}$ of the ruminal liquor by the effect of the pericarp and the entire fruit of Sapindus saponaria. Increased rumen $\mathrm{pH}$ favours the development and activity of cellulolytic bacteria, thus improving fiber digestion, DM intake and development performance (Zinn et al., 1999). Supplementation of saponin-rich plants to $\mathrm{NG}$ did not alter the $\mathrm{NH}_{3}$ concentration in comparison with the control treatment. The range of $\mathrm{NH}_{3}$ in the current study ranged from 19.1 to $22.2 \mathrm{mM}$, which was a little higher than the optimum concentration to support microbial protein synthesis based on McDonald et al. (2002) i.e. 6-21 mM. A tendency of lower ammonia concentration in $\mathrm{LF}$ and $\mathrm{NG}+\mathrm{LF}$ combination could be because of the antiprotozoal activity of LF. The reduced number of protozoa leads to lower bacterial lysis and thus reduced release of protein breakdown products. The well-documented effects of saponins on protozoal action and the following reduction in bacterial protein turnover (Wallace, 2004) could help in explaining the impact of saponins on rumen ammonia levels, but it is still unclear to what extent saponins disrupt the dietary protein breakdown. However, Muetzel et al. (2003) stated that saponins from sesbania did not prevent feed protein from being degraded in vitro. Apart from saponin, different protein fractions present in the feed materials also determine ammonia concentration in the rumen (Jayanegara et al., 2016).

Adding saponin supplement either singly or in combination significantly $(\mathrm{P}<0.05)$ reduced methane production in terms of \%TVFA as compared to NG. Saponins may lower methane emission by eliminating the rumen protozoa population because of the capacity of saponins to bind the sterol in the protozoa cell membranes, resulting in cell lysis (Hristov et al., 1999). Methane emissions have a close relationship with

Table 3. Effect of Experimental Diets on Ruminal pH, Ammonia $\left(\mathrm{NH}_{3}\right)$ and Methane $\left(\mathrm{CH}_{4}\right)$ Formation

\begin{tabular}{|c|c|c|c|}
\hline Diet & $\mathrm{pH}$ & $\mathrm{NH}_{3}(\mathrm{mM})$ & $\mathrm{CH}_{4}(\%$ TVFA $)$ \\
\hline NG & 7.05 & 20.7 & $36.9^{\mathrm{c}}$ \\
\hline GL & 7.08 & 22.2 & $36.3^{b c}$ \\
\hline $\mathrm{LF}$ & 7.07 & 19.1 & $35.1^{\mathrm{a}}$ \\
\hline HL & 6.87 & 21.3 & $36.8^{\mathrm{c}}$ \\
\hline NG $70 \%+$ GL $30 \%$ & 6.94 & 20.0 & $36.7^{\mathrm{c}}$ \\
\hline NG $70 \%+$ LF $30 \%$ & 6.98 & 19.2 & $36.1^{\mathrm{ab}}$ \\
\hline NG $70 \%+$ HL $30 \%$ & 6.81 & 21.3 & $36.9^{\mathrm{c}}$ \\
\hline SEM & 0.059 & 0.442 & 0.150 \\
\hline P-value & 0.254 & 0.374 & $<0.001$ \\
\hline
\end{tabular}

Different superscripts within the same column are significantly different at $\mathrm{P}<0.05$.

NG: napier grass, GL: gliricidia leaves, LF: lerak fruits, HL: hibiscus leaves, TVFA: total volatile fatty acids, SEM: standard error of mean. 
the quantum of rumen fermented $\mathrm{OM}$ or the quantum of digestible $\mathrm{OM}$ as more than half of digestion takes place in the rumen. Since the proportion of the individual VFAs is affected by the OM composition of the diet, mostly by the nature and rate of fermentation of carbohydrates, these dietary features will have substantial effect on methane production. Starch rich diets encourage propionate production, lowers the methane production/fermented $\mathrm{OM}$ ratio in the rumen. In contrast, a roughage-based diet will enhance the ratio (Moss et al., 2000).

The effects of experimental diets on ruminal VFA profiles are shown in Table 4. There were no significant differences in total VFA among the diets. Supplementation of saponin-rich plants has shifted VFA proportion towards more propionate and less acetate. This kind of shift in VFA proportion due to saponin supplementation of ruminant animal has been reported earlier (Makkar et al., 1995). A number of studies have noted higher propionate production at the expense of acetate and butyrate production, whereas others have observed no effect. Part of this change is definitely due to differences in saponin type and intensity, but it is interesting to note that the effect appears to be more marked (increase in propionate) in the case of a diet rich in grain or starch is used (Suharti et al., 2011) contrary to fibre-rich diets or mixed forages (Hess et al., 2003). This indicates that the diet may impact the response to saponin supplementation. Propionate proportion with the addition of LF supplementation neither single nor in combination with NG shows enhanced fermentation efficiency by rumen microbes. These results are supported by Suharti et al. (2011) who found a significant increase of propionate proportion following saponin extract addition. The higher propionate production lower the supply of $\mathrm{H}_{2}$ as the production of propionate in the metabolic pathway in the rumen utilises $\mathrm{H}_{2}$, which is in competition with methanogenic bacteria in the formation of methane. As such, the use of LF as a supplement holds great promise for the purpose of reducing methane production in the rumen. Earlier research has reported that tea saponin at a level of $0.5 \% \mathrm{DM}$ considerably raised propionate, lowered acetate proportion and reduced methane emissions (Beauchemin et al., 2008).

The microbial population of LF, whether single or in combination had a tendency to reduce

Table 4. Effect of Experimental Diets on Ruminal Volatile Fatty Acid Profiles

\begin{tabular}{|c|c|c|c|c|c|c|c|}
\hline Diet & $\begin{array}{l}\text { TVFA } \\
(\mathrm{mM})\end{array}$ & Acetate & Propionate & Isobutyrate & Butyrate & Isovalerate & Valerate \\
\hline \multicolumn{8}{|c|}{ 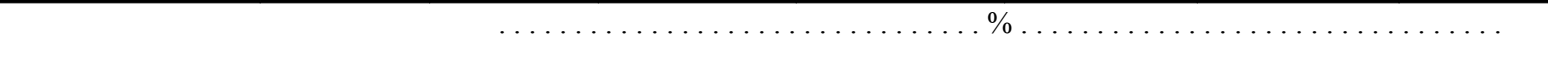 } \\
\hline NG & 53.6 & $84.5^{\mathrm{d}}$ & $9.18^{\mathrm{a}}$ & 0.76 & 3.91 & $1.08^{\mathrm{ab}}$ & 0.57 \\
\hline GL & 50.6 & $82.9^{\mathrm{bc}}$ & $10.27^{\mathrm{a}}$ & 1.17 & 3.31 & $0.41^{\mathrm{ab}}$ & 0.48 \\
\hline $\mathrm{LF}$ & 55.7 & $81.7^{\mathrm{a}}$ & $11.54^{\mathrm{b}}$ & 1.51 & 3.75 & $0.51^{\mathrm{a}}$ & 0.56 \\
\hline HL & 51.8 & $84.4^{\mathrm{d}}$ & $9.32^{\mathrm{a}}$ & 0.68 & 3.61 & $0.56^{\mathrm{b}}$ & 0.65 \\
\hline $\begin{array}{c}\mathrm{NG} 70 \%+\mathrm{GL} \\
30 \%\end{array}$ & 53.4 & $84.6^{\mathrm{d}}$ & $9.96^{\mathrm{a}}$ & 0.65 & 3.41 & $0.94^{\mathrm{a}}$ & 0.48 \\
\hline $\begin{array}{c}\text { NG } 70 \%+\mathrm{LF} \\
30 \%\end{array}$ & 51.1 & $82.9^{b}$ & $11.50^{\mathrm{b}}$ & 0.76 & 3.59 & $0.74^{\mathrm{a}}$ & 0.48 \\
\hline $\begin{array}{c}\mathrm{NG} 70 \%+\mathrm{HL} \\
30 \%\end{array}$ & 50.6 & $84.2^{\mathrm{d}}$ & $9.28^{\mathrm{a}}$ & 0.77 & 3.97 & $1.11^{\mathrm{ab}}$ & 0.64 \\
\hline SEM & 2.59 & 0.200 & 0.222 & 0.097 & 0.113 & 0.053 & 0.024 \\
\hline P-value & 0.991 & $<0.001$ & $<0.001$ & 0.101 & 0.060 & 0.010 & 0.133 \\
\hline
\end{tabular}

Different superscripts within the same column are significantly different at $\mathrm{P}<0.05$.

NG: napier grass, GL: gliricidia leaves, LF: lerak fruits, HL: hibiscus leaves, TVFA: total volatile fatty acids, SEM: standard error of mean 
Table 5. Effect of Experimental Diets on Ruminal Microbial Population ( $\log$ cell $/ \mathrm{mL})$

\begin{tabular}{ccccccc}
\hline Feed & $\begin{array}{c}\text { Total } \\
\text { bacteria }\end{array}$ & $\begin{array}{c}\text { Ruminococcus } \\
\text { flavefaciens }\end{array}$ & $\begin{array}{c}\text { Ruminococcus } \\
\text { albus }\end{array}$ & $\begin{array}{c}\text { Fibrobacter } \\
\text { succinogenes }\end{array}$ & $\begin{array}{c}\text { Total } \\
\text { protozoa }\end{array}$ & Methanogen \\
\hline NG & 10.5 & $5.42^{\mathrm{bc}}$ & 7.23 & 6.56 & 5.73 & 7.06 \\
GL & 10.7 & $4.46^{\mathrm{ab}}$ & 7.20 & 6.27 & 5.76 & 6.90 \\
LF & 10.6 & $5.63^{\mathrm{bc}}$ & 7.11 & 6.46 & 4.59 & 7.06 \\
HL & 10.7 & $5.52^{\mathrm{bc}}$ & 6.93 & 6.75 & 6.37 & 6.97 \\
NG 70\% + GL & & & & & & \\
$30 \%$ & 10.7 & $5.77^{\mathrm{bc}}$ & 7.47 & 6.55 & 4.23 & 7.11 \\
NG 70\% + LF & & & & & & \\
$30 \%$ & 10.6 & $4.08^{\mathrm{a}}$ & 7.14 & 6.19 & 5.25 & 6.99 \\
NG 70\% + HL & & & & & & \\
$30 \%$ & 10.8 & $5.97^{\mathrm{c}}$ & 7.61 & 6.72 & 5.62 & 7.28 \\
\hline $\begin{array}{c}\text { SEM } \\
\text { P-value }\end{array}$ & 0.063 & 0.186 & 0.089 & 0.248 & 0.154 & 0.052 \\
\hline
\end{tabular}

Different superscripts within the same column are significantly different at $\mathrm{P}<0.05$.

NG: napier grass, GL: gliricidia leaves, LF: lerak fruits, HL: hibiscus leaves, SEM: standard error of mean

the rumen protozoa population (Table 5). Reducing protozoal counts by supplementing with saponins-rich extract (Patra et al., 2006) or pod and seed (Wanapat et al., 2013) or fruits (Hess et al., 2003) has been reported previously. The effect of supplemented and non-supplemented saponins, either single or in combination with NG did not significantly reduce the rumen total bacteria population in the present study. Our data are in congruence with Wanapat et al. (2013) who reported the composition of total bacteria and genera ciliate protozoa populations had no effect on the herbs supplemented group. Methanogen population, in contrast to our expectation, was not altered by supplementation of saponin-rich materials.

The number of $R$. flavefaciens tended to increase in the blend with $\mathrm{HL}$ in the present study. Muetzel et al. (2003) also noted an increase in $R$. flavefaciens which is one of the predominant fiber-degrading bacteria (Wang et al., 2000) when tested with saponin-containing $S$. pachycarpa leaves in vitro. The population of the predominant fiber-degrading bacteria resulted from LF diet is in agreement with other findings using yucca saponin (Ningrat et al., 2002). Fibrobacter succinogenes was not affected, but Ruminococcus albus and $R$. flavefaciens were practically unable to degrade cell wall components in the presence of yucca saponins. The authors arrived at the conclusion that yucca saponin had more adverse effect on the Grampositive bacteria as compared to those of the Gram-negative bacteria. Muetzel et al. (2003) also reported that $S$. pachycarpa did not affect $F$. succinogenes (Gram-negative). Another study in pure culture demonstrated that the development of cellulolytic bacteria was reduced to a small extent when lerak extract was added in the culture (Ningrat et al., 2002).

\section{CONCLUSION}

In general, using saponin-containing plant (Hibiscus rosa-sinensis) alone or blended with Napier grass produces the highest IVOMD during the fermentation process. Incorporation of $30 \%$ lerak fruit decreases methane emission, and alters VFA profiles toward more propionate at the expense of acetate.

\section{ACKNOWLEDGMENTS}

The authors are grateful to the Department of Animal Science, Faculty of Agriculture, Universiti Putra Malaysia for the facilitation of 
this study through Research Attachment Program. The first author is grateful to Indonesian Ministry of Education and Culture (Kemendikbud) for the Doctoral Scholarship award (2015-2018).

\section{REFERENCES}

Abdulrazak, S.A., T. Fujihara, J.K. Ondilek and E.R. Orskov. 2000: Nutritive evaluation of some Acacia tree leaves from Kenya. Anim. Feed Sci. Technol. 85: 89-98.

Association of Official Analytical Chemists (AOAC). 1990. Association of Official Methods of Analysis. AOAC, Arlington, VA, USA.

Beauchemin, K.A., M. Kreuzer, F. O'Mara and T.A. McAllister, 2008. Nutritional management for enteric methane abatement: a review. Aust. J. Exp. Agric. 48:21-27.

Blummel, M. and E.R. Orskov. 1993. Comparison of in vitro gas production and nylon bag degradability of roughages in predicting of food intake in cattle. Anim. Feed. Sci. Technol. 40: 109-119.

Cheok, C.Y., H.A.K. Salman, R. Sulaiman. 2014. Extraction and quantification of saponins: a review. Food Res. Int. 59:16-40.

Dawson, I. K., A. J. Simons, R. Waugh and W. Powell. 1996. Detection and pattern of interspecific hybridization between Gliricidia sepium and G. maculata in MesoAmerica revealed by PCR-based assays. Mol. Ecol. 5:89-98.

Cottle, D.J., J.V. Nolan and S.G. Wiedemann. 2011. Ruminant enteric methane mitigation: a review. Anim. Prod. Sci. 51:491-514.

Cottyn, B.G., and C.V. Bouque. 1968. Rapid method for gas-chromatographic determination of volatile fatty acid in rumen fluids. J. Agric Food Chem. 16:105-107.

Hess, H.D., M. Kreuzer, T.E. D, J.E. Carulla, C.R. Soliva and A. Machmüller. 2003.Saponin rich tropical fruits affect fermentation and methanogenesis in faunated and defaunated rumen fluid. Anim. Feed Sci. Technol. 109 (1-4):79-94

Herdian, H., L. Istiqomah, A. Febrisiantosa, D. Setiabudi. 2011. Pengaruh penambahan daun morinda citrifolia sebagai sumber saponin terhadap karakteristik fermentasi, defaunasi protozoa, produksi gas dan metana cairan rumen secara in vitro. JITV. 16:99-104.

Hiai, S., and T. Nakajima. 1976. Color Reaction of some sapogenins and saponins with vanillin and sulfuric acid. Planta Med., 29:116-122.

Hristov, A.N., J. Oh, F. Giallongo, W.T. Freederick, T.M. Harper, L.H. Weeks, F.A. Branco, J.P. Moate, H.M. Deighton, O.R. Williams, M. Kinderman, S. Duval. 2017. An inhibitor persistenly decresed enteric methane emission from dairy cows with no negative effect on milk production. PNAS.112:10663-10668.

Hristov, A.N., T.A. McAllister, F.H. Van Herk, K.J. Cheng, C.J. Newbold and P.R. Cheeke. 1999. Effect of Yucca schidigera on ruminal fermentation and nutrient digestion in heifers. J. Anim. Sci. 77:2554-2563.

Jayanegara, A., A.S. Tjakradidjaja and T. Sutardi. 2006. Fermentabilitas dan kecernaan in vitro ransum limbah agroindustri yang disuplementasi kromium organik dan anorganik. Med. Pet. 29:54-62.

Jayanegara, A., E. Wina, C.R. Soliva, S. Marquardt, M. Kreuzer, and F. Leiber. 2011. Dependence of forage quality and methanogenic potential of tropical plants on their phenolic fractions as determined by principal component analysis. Anim. Feed Sci. Technol. 163:231-243.

Jayanegara, A., S.P. Dewi, N. Laylli, E.B. Laconi, Nahrowi, and M. Ridla. 2016. Determination of cell wall protein from selected feedstuffs and its relationship with ruminal protein digestibility in vitro. Med. Pet. 39:134-140.

Jeyanathan, J.C Martin, D. Morgavi. 2014. The use directed-fed microbals for mitigation of ruminant methane emissions: a review. Anim. 8: 250-261. 7.

Khazal K., X. Markantonatos, A. Nastis, E.R. Orskov. 1993. Changes with maturity in fibre composition and levels of extractable polyphenols in Greek browse: effect in vitro gas production and in sacco dry matter degradation. J. Sci. Food Agric. 63:237244.

Kondo, M., Y. Hirano, N. Ikai, K. Kita, A. Jayanegara, H.O. Yokota. 2014. Assessment of anti-nutritive activity of tannins in tea by-products based on in vitro rumen fermentation. Asian Australas. J. Anim. Sci. 27:1571-1576.

Kumar, S., P.K Choudhury, M.D. Carro, G.W. Griffith, S.S Dagar, M. Puniya, S. Calabro, S.R. Ravella, T. Dhewa, R.C. Upadhyay, 
S.K. Sirohi, S.S Kundu, M. Wanapat, A.K. Puniya. 2014. Newaspects and strategies formethane mitigation from ruminants. Appl. Microbiol. Biotechnol. 98:31-44.

Makkar, H.P.S., M. Bliimmel, K. Becker. 1995 Formation of complexes between polyvinyl pyrrolidones and polyethylene glycols with tannins and their implications in gas pro duction and true digestibility in in vitro techniques. Br. J. Nutr. 73:897-91

McDonald, P., R.A Edwards and J.F.D. Greenhalgh. 2002. Animal Nutrition. 6th Edition. Longman, London, UK.

Menke, K.H. and H. Steingass, 1988. Estimation of the energetic feed value obtained from chemical analysis and in vitro gas production using rumen fluid. Anim. Res. Dev. 28:7-55.

Moss, A.R., J.P. Jouany, J. Newbold. 2000. Methane production by ruminants:its contribution to global warming. a review. Ann.Zootech. 49(3):231-253

Muideen, A.A., A.R. Alimon, S. Jusoh, K.D. Adeyemi, M.F. Jahromi, and A.A. Samsudin. 2017. Effects of dietary Kleinhovia hospita and Leucaena leucocephala leaves on rumen fermentation and microbial population in goats fed treated rice straw. Trop. Anim. Health Prod. 49:1749-1756.

Muetzel, S., E.M. Hoffmann, K. Becker. 2003. Supplementation of barley strawwith Sesbania pachycarpa leaves in vitro: effects on fermentation variables and rumen microbial population structure quantified by ribosomal RNA-targeted probes. Br. J. Nutr. 89:445-453.

National Academy of Sciences. 1977. Leucaena a Promising Forage and Free Crop for the Tropics. National Academy of Science, Washington, DC.

Neumann, B., A. Pospiech, H.U. Schairrer. 1992. Rapid isolation of genomic DNA from Gram-negative bacteria. Trends Genet. 8: 332-333.

Ningrat, R.W.S., P.C. Garnsworthy, C.J. Newbold, 2002. Saponin fractions in Sapindus rarak: effects on rumen microbes. Reprod. Nutr. Dev. 42 (Suppl.1), S82.

Ørskov E.R., and P. McDonald. 1979: The estimation of protein degradability in the rumen from incubation measurements weighed according to rate of passage. J. Agric.Sci. 92:499-503.
Parsons T.R., Y. Maita, C.M Lalli. 1984. A Manual of Chemical and Biological Methods for Seawater Analysis. Elmsford, NY: Pergamon Press.

Patra, A.K., D.N. Kamra and N. Agarwal. 2006. Effect of plant extracts on in vitro methanogenesis, enzyme activities and fermentation of feed in rumen liquor of buffalo. Anim. Feed Sci. Technol. 128:276291.

Prusty, S. Mohini, S. Kundu, S. Kumar, A.C Datt. 2014. Methane emissions from river buffaloes fed on green fodders in relqation tothe nutrient intake and digestibility.Trop.Anim. Health Prod. 46: 65-70.

Rira, M., A. Chentli, S. Boufenera, H. Bousseboua. 2015. Effects of plants containing secondary metabolites on ruminal methanogenesis of Sheep in vitro. Energy Procedia. 74:15-24.

Steel, R.G.D. and J.H. Torrie. 1980. Principles and Procedures of Statistics: A Biometrical Approach. 2nd Ed. McGraw-Hill Book Company, New York, USA.

Steingass, H. and K.H. Menke. 1986. Schatzung des energetischen Futterwertes aus der in vitro mit Pansensaft "bestimmten Gasbildung und der chemischen Analyse. Tierernahrung. 14: 251.

Suharti, S., D.A. Astuti, E. Wina and T. Toharmat. 2011. Rumen Microbial Population in the In vitro Fermentation of Different Ratios of Forage and Concentrate in the Presence of Whole Lerak (Sapindus rarak) Fruit Extract. Asian-Austr. J. Anim. Sci.,24:1086-1178.

Teferedegne, B., F. McIntosh, P., O. Osuji, A. Odenyo, R.J. Wallace and C.J. Newbold. 1999. Influence of foliage from different accessions of the sub-tropical leguminous tree, Sesbania sesban, on ruminal protozoa in Ethiopian and Scottish sheep. Anim. Feed Sci. Technol. 78:11-20.

Tian, H., C. Lu, P. Ciais, A.M. Michalak, J.G Canadell, E. Saikawa, D.N. Huntzinger, K.R. Gurney, S.Sitch and B. Zhang, 2016. The terrestrial biosphere as a net source of greenhouse gases to the atmosphere. Nature, 531:225-228.

Van Soest, P. J., J.D. Robertson and B.A. Lewis. 1991. Methods for dietary fibre, neutral detergent fibre and non-starch polysaccharides in relation to animals nutrition. J. Dairy Sci. 74:3583-3597 
Wallace, R.J. 2004. Antimicrobial properties of plant secondary metabolites. P. Nutr. Soc., 63:621-629.

Wanapat, M., N. Anantasook, P. Rowlinson, R.G. Pilajun and P. Gunun. 2013 Effect of carbohydrate sources and levels of cotton seed meal in concentrate on feed intake, nutrient digestibility, rumen fermentation and microbial protein synthesis in young dairy bulls. Asian Aust. J. Anim. Sci. 26:529-536.

Wang, Y., T.A. McAllister,L.J. Yanke, Z.J. Xu, P.R. Cheeke and K.J. Cheng. 2000. In Vitro effects of steroidal saponins from Yucca schidigera extract on rumen microbes. J. Appl. Microbiol. 88:887-896.

Wina, E., S. Muetzel and K. Becker, 2006. The dynamics of major fibrolytic microbes and enzyme activity in the rumen in response to short- and long-term feeding of Sapindus rarak saponins. J. Appl. Microbiol. 100: 114-122.

Wojciechowski, K., M. Orczyk, T. Gutberlet and T. Geue. 2016. Complexation of phospholipids and cholesterol by triterpenic saponins in bulk and in monolayers. Biochim. Biophys. Acta.1858: 363-373

Wood, C.D., J.L. Stewart and J.E. Vargas. 1998. Genetic variation in the nutritive value of Gliricidia sepium.: 2. Leaf chemical composition and fermentability by an in vitro gas production technique. Anim. Feed Sci. Technol. 75(2):125-143.

Zailan, M.Z., H. Yaakub and S. Jusoh. 2015. Yield and nutritivevalueof Napier cultivars at different harvesting ages. Proceeding of the 35th Malaysian Society of Animal Production (MSAP), Port Dickson, Negeri Sembilan,Malaysia, 1-3 June2015.

Zinn, R.A. and J. Salinas. 1999. Influence of fibrozyme on digestive function and growth performance of feedlot steers fed a 78\% concentrate growing diet. In: Biotechnology in Feed Industry, Lyons, TP and Jaccques KA, (eds) Alltech Inc, Nottingham University Press, Loughborough, UK. Pp 313-319. 